\title{
Localization of epididymal secretory proteins on rat spermatozoa
}

\author{
D. E. Brooks and K. Tiver \\ Department of Animal Sciences, Waite Agricultural Research Institute, University of Adelaide, \\ Glen Osmond, South Australia 5064, Australia
}

\begin{abstract}
Summary. Spermatozoa from the testis and cauda epididymidis of the rat were surface labelled with radioactive iodide. Detergent extracts of radioiodinated spermatozoa immunoprecipitated with antisera against specific epididymal proteins, followed by polyacrylamide gel electrophoresis, revealed two proteins (D and E of $M_{r} 27000$ and 28000 , respectively) which became associated with spermatozoa during epididymal transit. These proteins were observed by immunofluorescence microscopy to be located over a restricted area of the head surface. Proteins with similar molecular weight were labelled on spermatozoa from the cauda epididymidis, but not from the testis, by reaction with sodium boro $\left[{ }^{3} \mathrm{H}\right]$ hydride in the presence of galactose oxidase. However, failure to immunoprecipitate with antibodies to Proteins D and E and non-coincident migration on two-dimensional gel electrophoresis established the non-identity of these proteins. Compared with Proteins D and E, two other major epididymal secretory proteins (Proteins B and $C$ of $M_{r} 16000$ ) associated with spermatozoa to a relatively minor extent during epididymal transit.
\end{abstract}

\section{Introduction}

Sperm maturation in the epididymis is accompanied by alterations in certain sperm surface characteristics such as surface charge (Bedford, 1963), pI and membrane lability (Hammerstedt, Hay \& Amann, 1982), antigenic composition (Killian \& Amann, 1973), lectin binding (Nicolson, Usui, Yanagimachi, Yanagimachi \& Smith, 1977), zona binding (Saling, 1982), and membrane transport (Hiipakka \& Hammerstedt, 1978). While some of these changes may be intrinsic to the spermatozoa themselves, others are probably brought about by an interaction between the spermatozoon and the surrounding epididymal fluid. In particular, there is evidence that certain epididymal secretory proteins become firmly associated with the sperm surface (see Killian \& Amann, 1973; Lea, Petrusz \& French, 1978; Kohane, González Echeverría, Piñeiro \& Blaquier, 1980; Voglmayr, Fairbanks, Jackowitz \& Colella, 1980; Bayard, Duguet, Mazzuca \& Faye, 1981; Dravland \& Joshi, 1981; Moore, 1981; Wong \& Tsang, 1982). In the rat, Cameo \& Blaquier (1976) first described some androgen-dependent and epididymal-specific proteins which migrated faster than albumin during polyacrylamide gel electrophoresis under non-denaturing conditions. These proteins were assigned the letters $B, C, D$ and $E$ according to their migration position in front of albumin (A). A summary of the characteristics of these epididymal secretory proteins can be found in Brooks (1981b). Proteins B and C ( $\left.\mathbf{M}_{r} 16000\right)$, Protein D $\left(M_{r} 27000\right)$, and Protein E $\left(M_{r} 28000\right)$ have been purified and antisera have been raised against them (Brooks \& Higgins, 1980; Brooks, $1981 \mathrm{a}, 1982)$. In the present study these antisera have been used to investigate whether the secretory proteins become associated with spermatozoa during epididymal transit and where they are distributed over the sperm surface. 


\section{Materials and Methods}

Chemicals. Details of the sources of most chemicals have been given previously (Brooks, 1981a). IgGsorb, a preparation of killed Staphylococcus aureus, was obtained from The Enzyme Center, Inc., Boston, Massachusetts, U.S.A. Sodium boro $\left[{ }^{3} \mathrm{H}\right]$ hydride (sp. act. $155.5 \mathrm{Ci} / \mathrm{mmol}$ in $0.5 \mathrm{M}-$ $\mathrm{NaOH}$ ) and sodium [ $\left.{ }^{125} \mathrm{I}\right]$ iodide (sp. act. $15 \mathrm{mCi} / \mu \mathrm{g}$ iodine) were from Amersham Australia Pty Ltd, Sydney, Australia. Cyanogen bromide-activated Sepharose 4B was from Pharmacia (South Seas) Pty Ltd, North Ryde, New South Wales. Proteins were coupled to cyanogen bromideactivated Sepharose 4B according to instructions supplied by the manufacturer. Glucose oxidase, fluorescein isothiocyanate (FITC)-labelled rabbit anti-goat $\mathrm{IgG}(23.3 \mathrm{mg}$ protein/ml with a fluorochrome/protein molar ratio of 4.05) and bovine serum albumin (fraction V) were from Sigma Chemical Co., St Louis, Missouri, U.S.A. Iodo-Gen (1,3,4,6-tetrachloro-3 $\alpha, 6 \alpha$-diphenylglycoluril) was purchased from Pierce Chemical Co., Rockford, Illinois, U.S.A.

Collection of spermatozoa and epididymal luminal fluid. Adult male Sprague-Dawley rats were used. Testicular spermatozoa were collected by puncturing the rete testis of a rat whose efferent ducts had been ligated $24 \mathrm{~h}$ previously (Waites, 1977). Spermatozoa from the cauda epididymidis and epididymal luminal fluid were collected from the same animal by retrograde perfusion via the ductus deferens (Brooks, Hamilton \& Mallek, 1974; Wong \& Yeung, 1978). Little is known about changes in the characteristics of rete testis fluid and spermatozoa following efferent-duct ligation, but the studies of Free \& Jaffe (1979) suggest that such changes are minimal. Spermatozoa were diluted into PBS (phosphate-buffered saline: $10 \mathrm{~mm}$-sodium phosphate, $140 \mathrm{~mm}-\mathrm{NaCl}, \mathrm{pH} 7 \cdot 4$ ) to 4 $\times 10^{7}$ cells $/ \mathrm{ml}$. The spermatozoa were washed 3 times by centrifugation at $600 \mathrm{~g}$ for $5 \mathrm{~min}$ and resuspension in $1 \mathrm{ml}$ PBS or Ringer $\left(150 \mathrm{mM}-\mathrm{Na}^{+}, 4.8 \mathrm{mM}-\mathrm{K}^{+}, 1.3 \mathrm{mM}-\mathrm{Ca}^{2+}, 1.2 \mathrm{mM}-\mathrm{Mg}^{2+}\right.$, $129 \mathrm{mM}^{-\mathrm{Cl}^{-}}, 15.5 \mathrm{~mm}^{-} \mathrm{PO}_{4}{ }^{3-}, 1.2 \mathrm{mM}^{-} \mathrm{SO}_{4}{ }^{2-}, 5 \mathrm{~mm}$-glucose, $\mathrm{pH} \mathrm{7.4)}$. After the final wash spermatozoa were usually resuspended to $4 \times 10^{7} / \mathrm{ml}$.

Crude membrane fractions were prepared from testicular and epididymal spermatozoa to prepare polyspecific antisera in rabbits against sperm surface antigens. Spermatozoa washed in PBS were further washed and resuspended in $10 \mathrm{~mm}-\mathrm{Hepes}, \mathrm{pH} 7 \cdot 0$, at $0^{\circ} \mathrm{C}$ and sonicated for $15 \mathrm{sec}$ at $100 \mathrm{~W}$. The sonicated suspension was centrifuged at $1000 \mathrm{~g}$ for $10 \mathrm{~min}$ and the supernatant recentrifuged at $100000 \mathrm{~g}$ for $30 \mathrm{~min}$. The crude membrane pellet was resuspended in $0.25 \mathrm{M}$ -

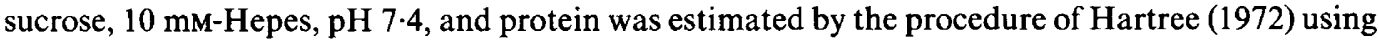
bovine serum albumin as the standard. Aliquants containing $200 \mu \mathrm{g}$ protein were stored at $-80^{\circ} \mathrm{C}$ for subsequent immunization by the protocol described previously (Brooks, 1982).

Affinity purification of antibodies. Epididymal secretory proteins, Proteins B and D, purified as described previously, were used to raise antisera in rabbits and goats (Brooks, 1981a, 1982). The specificity of antisera was ascertained by several methods to ensure that the antibodies were directed against the proteins of interest. These methods included (a) Ouchterlony double immunodiffusion against purified proteins, (b) crossed immunoelectrophoresis using nondenaturing polyacrylamide gel electrophoresis or isoelectric focussing of total epididymal luminal fluid proteins in the first dimension, and (c) two-dimensional gel electrophoresis of immunoprecipitates from epididymal luminal fluid proteins labelled with $\left[{ }^{35} S\right]$ methionine or [125I]iodide. Antiserum to Protein B also recognized Protein C (Brooks, 1981a). Similarly, antiserum to Protein D also recognized Protein E (Brooks, 1982).

Immunoglobulins were precipitated from serum with an equal volume of ammonium sulphate, washed in $40 \%$ saturated ammonium sulphate, dialysed against $10 \mathrm{~mm}$-sodium phosphate, $\mathrm{pH} 7 \cdot 4$ and centrifuged to remove insoluble material. For affinity purification of antibodies, the immunoglobulin solution was adjusted to $0.5 \mathrm{M}-\mathrm{KCl}$ and then passed through a column containing Protein B, or Protein D, coupled to Sepharose 4B. After washing out all unbound material, specific antibodies were eluted with $0.2 \mathrm{M}$-glycine, $0.5 \mathrm{M}-\mathrm{KCl}, \mathrm{pH} 2 \cdot 5$. Antibody-containing fractions were neutralized with $1 \mathrm{M}$-Tris, dialysed against $20 \mathrm{mM}-\mathrm{NH}_{4} \mathrm{HCO}_{3}$, freeze-dried and dissolved in PBS. Purification of the antibodies was monitored by Ouchterlony double immunodiffusion. 
Radioiodination of spermatozoa and reproductive tract fluids. Spermatozoa and epididymal fluids were iodinated by the procedure of Markwell \& Fox (1978) using glass tubes coated with Iodo-Gen ( $2 \mu \mathrm{g}$ for spermatozoa, $10 \mu \mathrm{g}$ for soluble epididymal proteins); $50 \mu$ l iodination premix (Ringer containing $20 \mu \mathrm{M}-\mathrm{KI}, 20 \mu \mathrm{M}$-sodium metabisulphite and $0.1 \mathrm{mCi} \mathrm{Na}{ }^{125} \mathrm{I}$ ) were placed in the IodoGen-coated tubes followed by $50 \mu \mathrm{l}$ washed sperm suspension $\left(4 \times 10^{7}\right.$ cells $/ \mathrm{ml}$ Ringer $)$ or $50 \mu \mathrm{l}$ Ringer containing $100 \mu \mathrm{g}$ soluble epididymal proteins. The tubes were incubated with shaking for $15 \mathrm{~min}$ at room temperature. After iodination, spermatozoa were washed 3 times in Ringer and extracted in $40 \mu \mathrm{l}$ 1\% Nonidet P-40, 1 mM-EDTA, 1 mM-phenylmethylsulphonylfuoride (PMSF), $10 \mathrm{~mm}$-Tris, $\mathrm{pH} 7 \cdot 2$, for $15 \mathrm{~min}$ at room temperature or in $40 \mu 11 \%$ sodium dodecyl sulphate, $1 \mathrm{mM}$ -

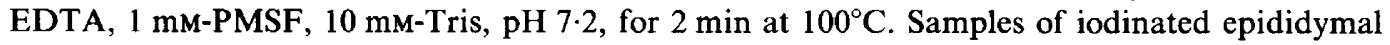
fluids and sperm extracts were stored at $-80^{\circ} \mathrm{C}$. Preparation and iodination of spermatozoa and epididymal fluids was replicated three times in the experiments described in this paper.

Labelling of spermatozoa with tritiated borohydride. Spermatozoa were washed by centrifugation through Hepes-buffered sucrose as described by Jones, Pholpramool, Setchell \& Brown (1981) and resuspended to $2 \times 10^{8} \mathrm{cells} / \mathrm{ml}$ in $0.25 \mathrm{~m}$-sucrose, $10 \mathrm{~mm}$-Hepes, $\mathrm{pH} \mathrm{8.0.} \mathrm{To} 100 \mu \mathrm{l}$ sperm

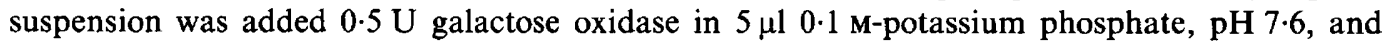
$0.25 \mathrm{mCi}$ sodium boro $\left[{ }^{3} \mathrm{H}\right]$ hydride contained in $12 \mu 10.5 \mathrm{M}-\mathrm{NaOH}$ freshly neutralized with $6 \mu 11 \mathrm{M}-$ Hepes. The spermatozoa were incubated with shaking at $32{ }^{\circ} \mathrm{C}$ for $20 \mathrm{~min}$ and then washed by

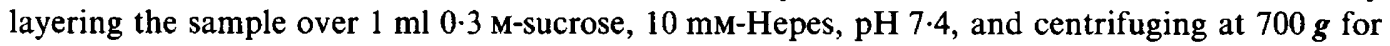
$4 \mathrm{~min}$. The sperm pellet was extracted in $50 \mu \mathrm{l} 1 \%$ Triton, $1 \mathrm{mm-EDTA}, 1 \mathrm{~mm}-\mathrm{PMSF}, 10 \mathrm{~mm}$-Tris, $\mathrm{pH} 7 \cdot 4$, for $1 \mathrm{~h}$ at $0^{\circ} \mathrm{C}$. The supernatant from centrifugation $(1 \mathrm{~min}$ at $10000 \mathrm{~g}$ ) was used for gel electrophoresis. The above experiments were carried out on two separate occasions.

Polyacrylamide gel electrophoresis. One-dimensional gel electrophoresis using the buffer systems of Laemmli (1970) for denaturing gels and of Davis (1964) for non-denaturing gels was carried out as described previously (Brooks, 1981a). Two-dimensional gel electrophoresis was based on the procedure of O'Farrell (1975) as described by Brooks (1983) employing isoelectric focussing in the first dimension and electrophoresis in the presence of sodium dodecyl sulphate in the second dimension. Immunoprecipitation of specific radioactive proteins before gel electrophoresis was by the procedure of Ivarie \& Jones (1979) using rabbit antisera and Staphylococcus aureus (IgGsorb) as the adsorbant for immune complexes. Gels were stained with Coomassie Brilliant Blue R250 to reveal protein distribution. Proteins labelled with tritiated borohydride were located by impregnating gels with PPO followed by fluorography at $-70^{\circ} \mathrm{C}$ using pre-flashed Fuji RX X-ray film (Laskey, 1980). The distribution of iodinated proteins was determined by autoradiography in which a dried gel was exposed to X-ray film at $-70^{\circ} \mathrm{C}$ in the presence of a Dupont Cronex Hi-Plus intensifying screen (Laskey, 1980).

Fluorescence microscopy. Spermatozoa washed 3 times in PBS and resuspended to $4 \times 10^{7}$ cells/ $\mathrm{ml}$ were treated with $2 \%$ formaldehyde (prepared freshly from paraformaldehyde) for $15 \mathrm{~min}$ at $0^{\circ} \mathrm{C}$; all subsequent steps were at room temperature. The fixed spermatozoa were washed twice in PBS by diluting the suspension 10-fold and centrifuging for $10 \mathrm{sec}$ at $10000 \mathrm{~g}$ (Microfuge: Beckman Instruments Inc., Palo Alto, California). The washed sperm pellet was resuspended in PBS containing $1 \%$ bovine serum albumin (PBS-A). Samples of $20 \mu$, each containing $0.8 \times 10^{6}$ spermatozoa, were then treated with $3 \mu \mathrm{g}$ affinity-purified goat IgG against Proteins B and C, or Proteins D and E, for $20 \mathrm{~min}$. The spermatozoa were washed 3 times in $0.5 \mathrm{ml}$ PBS-A and resuspended to $20 \mu \mathrm{l}$. Next, $10 \mu \mathrm{l}$ of 1/128 diluted FITC-labelled anti-goat IgG were added and mixed for $20 \mathrm{~min}$. The spermatozoa were then washed twice in $0.5 \mathrm{ml}$ PBS-A, once in $0.5 \mathrm{ml}$ PBS and finally resuspended in $20 \mu \mathrm{l}$ of $80 \%$ glycerol containing $0.1 \mathrm{M}$-Tris, pH 9.

Spermatozoa were examined in an Olympus BH-2 microscope fitted with an FITC epifluorescence kit. Photomicrographs were recorded on Kodak Tri-X film (400 ASA). Spermatozoa were prepared for indirect fluorescence microscopy, as described above, on four separate occasions with identical results on each occasion. 


\section{Results}

Demonstration by iodination and immunoprecipitation that specific epididymal secretory proteins become components of the sperm surface

Iodo-Gen was used to catalyse iodination of sperm surface proteins. Detergent extracts of radioiodinated spermatozoa were then treated with antiserum against Proteins $B$ and $C$, or Proteins $\mathrm{D}$ and $\mathrm{E}$, before polyacrylamide gel electrophoresis. The results demonstrate that spermatozoa from the cauda epididymidis, but not those from the testis, contain trace amounts of Proteins B and/or C (Pl. 1, Fig. 1, lanes 1 and 3). Proteins D and/or E were also present on cauda spermatozoa, but not on testicular spermatozoa, and in much greater amounts than Proteins B and/or C (Pl. 1, Fig. 1, lanes 2 and 4). Immunoprecipitation of radioiodinated epididymal luminal fluid proteins with the same antisera is shown in Pl. 1, Fig. 1, lanes 5 and 6. One-dimensional gel electrophoresis does not readily resolve Protein B from Protein C, and Protein D from Protein E. Therefore, twodimensional gel electrophoresis, which does have the ability to resolve these proteins, was also used in these analyses. Such gels revealed that the bands labelled B and D in P1. 1, Fig. 1 contained both Proteins $B$ and $C$, and D and E, respectively (results not shown). Antiserum against Protein D also precipitated from cauda spermatozoa a prominent band of $M_{r} 200000$ which was not observed in testicular spermatozoa or epididymal plasma (Pl. 1, Fig. 1, compare lane 4 with lanes 2 and 6). This band was not present when gels were run in the presence of mercaptoethanol which reduces disulphide bonds. This suggests that the $M_{r} 200000$ band seen in the absence of mercaptoethanol may represent Protein $\mathrm{D}$ and/or $\mathrm{E}$ bound to a sperm-surface protein by disulphide linkages.

The presence on spermatozoa from the cauda epididymidis of significant amounts of Proteins D and $\mathrm{E}$, but only trace amounts of Proteins $\mathbf{B}$ and $\mathbf{C}$, was confirmed by two-dimensional gel electrophoresis of whole extracts of radioiodinated spermatozoa, and whole extracts immunoprecipitated with polyspecific antisera against epididymal luminal fluid proteins (results not shown). It was established separately that these polyspecific antisera recognized Proteins B, C, D and E in addition to other epididymal luminal fluid proteins. Furthermore, polyspecific antisera raised against cauda epididymal sperm membranes have consistently failed to immunoprecipitate Proteins $\mathbf{B}$ and $\mathrm{C}$ from radioiodinated epididymal luminal fluid proteins, whereas such antisera readily immunoprecipitate Proteins D and E.

\section{PLATE 1}

Fig. 1. Gel electrophoresis and autoradiography of iodinated proteins of spermatozoa from the testis (lanes 1,2) and cauda epididymidis (lanes 3,4) and from epididymal luminal fluid (lanes $5,6)$ after immunoprecipitation with specific antisera. Iodinated proteins (see 'Materials and Methods') were immunoprecipitated with antiserum against epididymal Protein B (see Brooks, 1981 a) or Protein D (see Brooks, 1982), as indicated by the B or D above the gel lanes, before gel electrophoresis in the absence of mercaptoethanol. Equal numbers of testicular and cauda spermatozoa were used for iodination and equal volumes of detergent extracts of spermatozoa were taken for immunoprecipitation. Molecular weight $\left(M_{r} \times 10^{-3}\right)$ is shown by the scale at the side of the gel. The migration positions of epididymal Proteins $\mathrm{B}$ and D are also indicated.

Fig. 2. Gel electrophoresis and fluorography of radioactive products produced by treating rat spermatozoa with tritiated borohydride in the presence of galactose oxidase. Equal numbers of testicular and cauda spermatozoa were labelled with tritiated borohydride in the presence of galactose oxidase, and Triton extracts were separated by gel electrophoresis. (a) Fluorograph of a one-dimensional denaturing gel run in the absence of mercaptoethanol: lanes 1 and 3, cauda spermatozoa; lane 2, testicular spermatozoa. Galactose oxidase was omitted from the incubation in lane 1. (b) Fluorograph of a two-dimensional gel run in the presence of mercaptoethanol. Molecular weight $\left(M_{r} \times 10^{-3}\right)$ is shown by the scale at the side of the gel. The migration positions of epididymal Proteins $\mathrm{D}$ and $\mathrm{E}$ are also indicated. Note that these proteins run with different apparent molecular weights in the absence (a) or presence (b) of mercaptoethanol (see Brooks, 1982). The $\mathrm{pH}$ is indicated along the top of the gel. 
PLATE 1
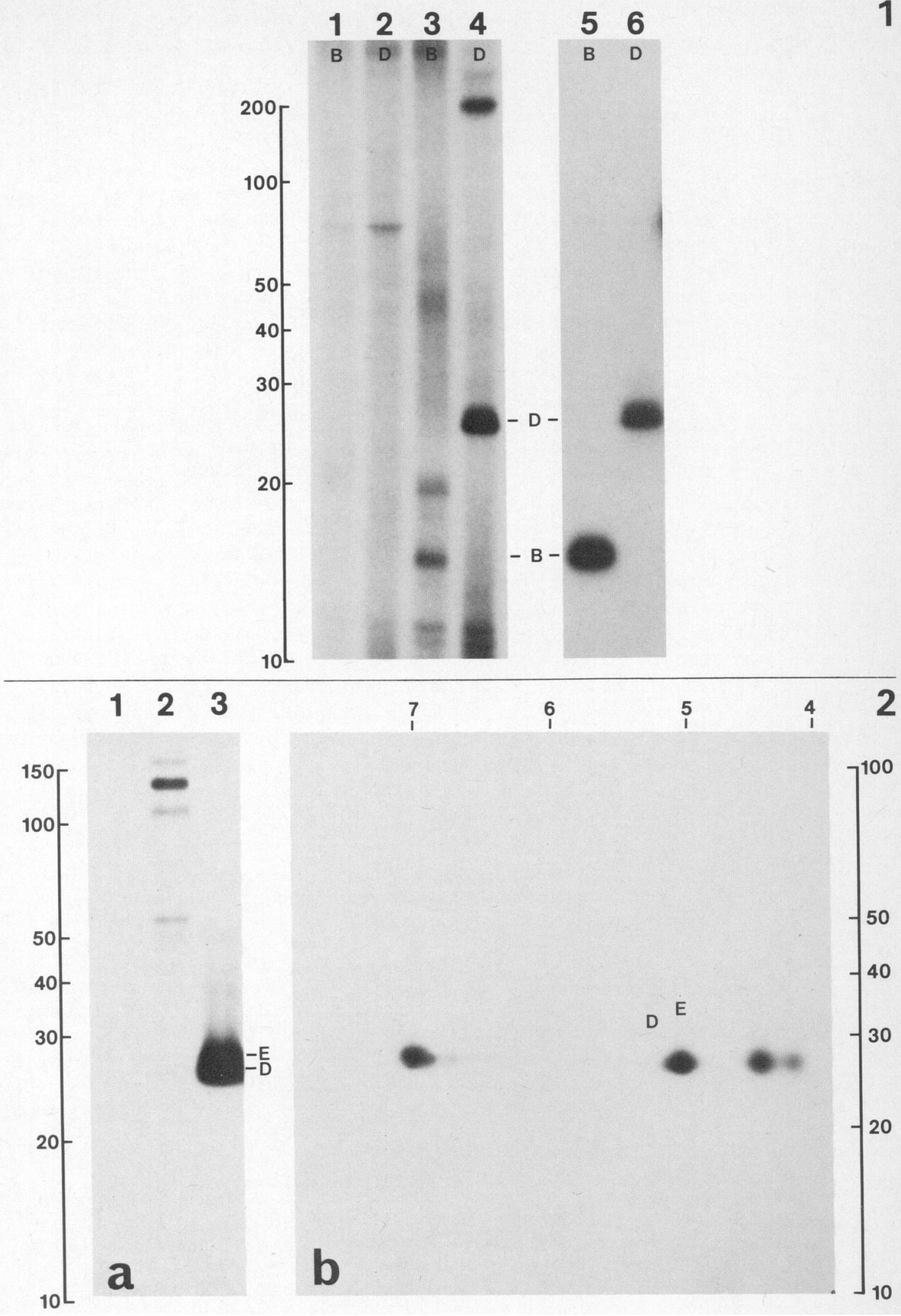


\section{Testicular spermatozoa}

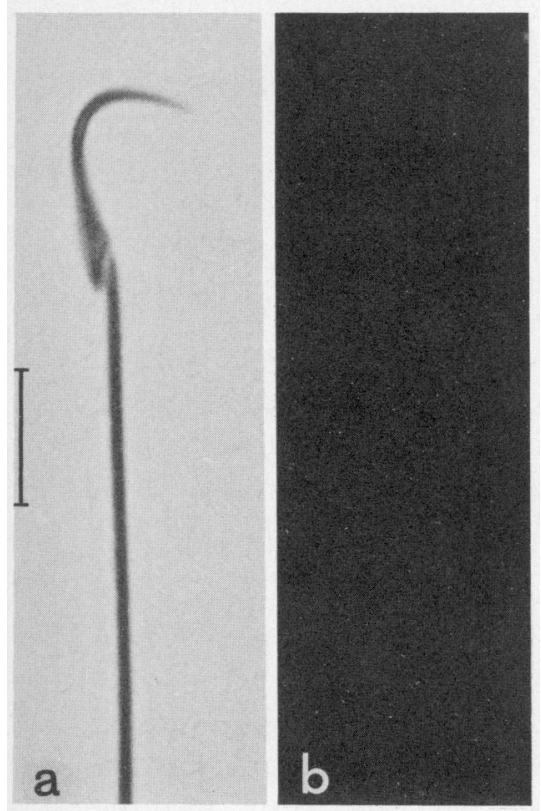

\section{Cauda spermatozoa}

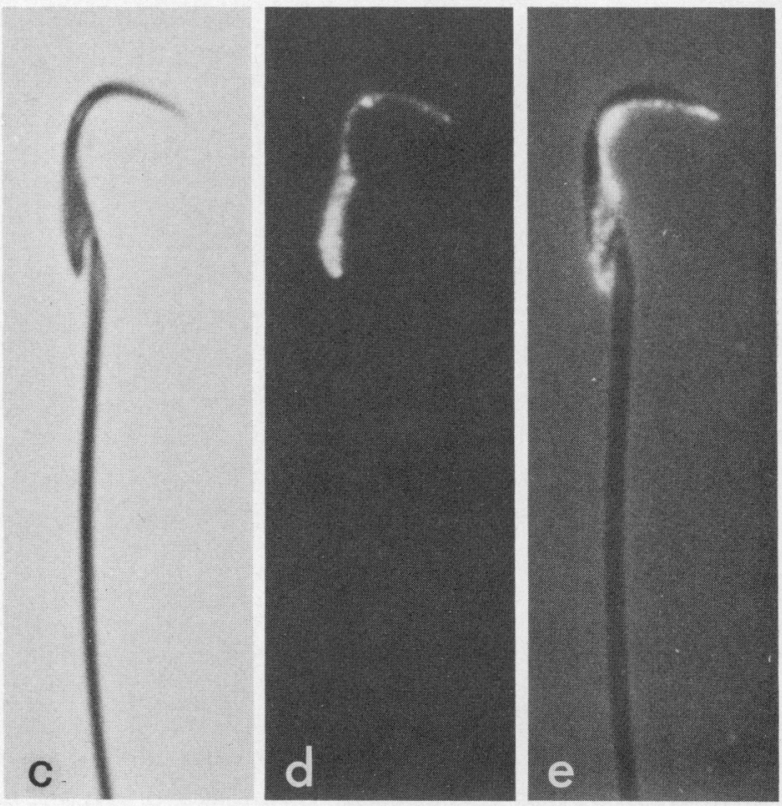

Fig. 3. Immunofluorescent localization of epididymal secretory proteins ' $D+E$ ' on rat spermatozoa by using affinity-purified antibodies. These results were obtained with formalinfixed spermatozoa as described in the 'Materials and Methods', but equivalent results were also obtained with unfixed spermatozoa or spermatozoa fixed in $2.5 \%$ glutaraldehyde in $0.1 \mathrm{M}$ sodium cacodylate, $\mathrm{pH} 7 \cdot 4$. Testicular spermatozoa: $\mathrm{a}$, phase contrast; $\mathrm{b}$, fluorescence. Cauda spermatozoa: c, phase constrast; $d$, fluorescence; e, phase contrast (low light level) plus fluorescence. All photomicrographs were taken through a $\times 40$ objective and are to the same magnification. The scale bar in (a) represents $10 \mu \mathrm{m}$. Substitution of pre-immune IgG for immune IgG resulted in the absence of fluorescence on cauda spermatozoa (results not shown). 
Surface labelling of spermatozoa with tritiated borohydride and galactose oxidase reveals surface modification during epididymal transit

A prominent band of $M_{r} 135000$ in testicular spermatozoa was labelled by tritiated borohydride in the presence of galactose oxidase (Pl. 1, Fig. 2a, lane 2). There was no equivalent band in cauda epididymal spermatozoa but a prominent band of $\mathrm{M}_{\mathrm{r}} 27000$, absent from testicular spermatozoa, was observed (Pl. 1, Fig. 2a, lane 3). No labelling occurred when galactose oxidase was omitted from the incubation (P1. 1, Fig. 2a, lane 1).

The borohydride-labelled band of $\mathrm{M}_{\mathrm{r}} 27000$, present in cauda but not testicular spermatozoa, migrated in the position of Proteins D and E. However, several gel electrophoretic procedures established that the borohydride-labelled band was not equivalent to either Protein D or Protein E. First, no radioactive band was immunoprecipitated with antiserum against Proteins $\mathrm{D}$ and $\mathrm{E}$ (results not shown). Second, the borohydride-labelled band did not co-migrate with Proteins D and E on non-denaturing gels (results not shown). Third, two-dimensional gel electrophoresis resolved the borohydride-labelled material into 4 spots, none of which migrated with authentic Protein D or E (Pl. 1, Fig. 2b). Moreover, Proteins D and E do not bind to the lectin from Ricinus communis, type II (Brooks \& Higgins, 1980) whereas the borohydride-labelled protein from spermatozoa does so (Olson \& Hamilton, 1978).

\section{Localization of epididymal proteins over specific regions of the sperm surface}

A double-antibody procedure was used to localize specific proteins on the sperm surface by immunofluorescence microscopy. Initial studies with unfractionated immunoglobulins proved unsatisfactory due to non-specific immunofluorescence and this was not greatly improved by absorption of immunoglobulins with a variety of tissue extracts. However, affinity purification of antibodies as described in the 'Materials and Methods' eliminated non-specific staining.

Immunofluorescence microscopy with affinity-purified antibodies failed to detect the presence of Proteins B and C on testicular or cauda spermatozoa. By contrast, antibodies against Proteins D and $\mathrm{E}$ produced strong fluorescence on the heads of cauda epididymal spermatozoa but not testicular spermatozoa (Pl. 2, Fig. 3). The fluorescence was restricted to the concave surface of the anterior region of the head, passing to the lateral head surfaces in the post-acrosomal region (Pl. 2, Fig. 3e).

\section{Discussion}

The present study has established that epididymal secretory proteins, Proteins D and E, which are both recognized by the same antiserum, become components of the sperm surface during epididymal transit. The proteins are localized to a specific area, namely the concave surface of the anterior of the head and the lateral surfaces of the post-acrosomal region of the head. Other characteristics of Proteins $\mathrm{D}$ and $\mathrm{E}$ indicate that they are equivalent to the androgen-dependent acidic epididymal glycoproteins described by others (e.g. Proteins D and E of Cameo \& Blaquier (1976) and Garberi, Kohane, Cameo \& Blaquier (1979); acidic epididymal glycoprotein (AEG) of Lea et al. (1978) and Lea \& French (1981); specific epididymal proteins (SEP) of Kohane, Garberi, Cameo \& Blaquier (1979); sialoprotein (SP) of Faye, Duguet, Mazzuca \& Bayard (1980) and Bayard et al. (1981); protein IV or 32K of Jones, Brown, von Glos \& Parker (1980) and Brown, von Glos \& Jones (1983); 32K protein of Wong \& Tsang (1982)). It has been suggested that these glycoproteins correspond to the glycoprotein of cauda spermatozoa which is accessible to labelling with tritiated borohydride in the presence of galactose oxidase (Olson \& Hamilton, 1978; Jones et al., 1981; Olson \& Danzo, 1981). However, the results of the present study have established that these moieties are not identical. 
Localization of rat epididymal glycoproteins on the sperm surface by immunofluorescence microscopy has been reported by Kohane et al. (1979), Bayard et al. (1981), Jones \& Brown (1982) and Brown et al. (1983). However, controls in which preimmune serum replaced immune serum and comparison of immature with mature spermatozoa have not always been reported and hence the specificity of the staining is not known. The surface distribution of Proteins $D$ and $E$ in the present study resembles that reported for specific epididymal proteins by Kohane et al. (1979) but is quite different from that observed by Bayard et al. (1981) for sialoprotein and Brown et al. (1983) for $32 \mathrm{~K}$ protein.

Jones \& Brown (1982) demonstrated immunofluorescent localization of two major secretory proteins of $M_{r} 18500$ and 19000 on the head and midpiece of cauda spermatozoa. These two proteins correspond in many other respects (see Brooks, 1981b) to Proteins B and C investigated in the present study. However, we were unable to demonstrate localization of these proteins on spermatozoa by immunofluorescent microscopy using affinity-purified antibody. Radioiodination and immunoprecipitation techniques confirmed that only trace amounts of these proteins were associated with spermatozoa.

Sperm-egg recognition is believed to involve specific and complementary receptors on the two gametes. Such receptors are presumably located on the sperm head rather than the tail since zona attachment and fusion with the vitelline membrane take place with the former region of the spermatozoa. Proteins D and E, being located on the sperm head, could fulfil a role as egg receptors but further work will be required to establish whether or not this is so.

We are grateful to the Australian Research Grants Scheme for financial assistance.

\section{References}

Bayard, F., Duguet, L., Mazzuca, M. \& Faye, J.C. (1981) Study of a glycoprotein produced by the rat epididymis. In Reproductive Processes and Contraception, pp. 393-405. Ed. K. W. McKerns. Plenum, New York.

Bedford, J.M. (1963) Changes in the electrophoretic properties of rabbit spermatozoa during passage through the epididymis. Nature, Lond. 200, $1178-$ 1180.

Brooks, D.E. (1981a) Secretion of proteins and glycoproteins by the rat epididymis: regional differences, androgen-dependence, and effects of protease inhibitors, procaine and tunicamycin. Biol. Reprod. 25, 1099-1117.

Brooks, D.E. (1981b) Metabolic activity in the epididymis and its regulation by androgens. Physiol. Rev. 61, 515-555.

Brooks, D.E. (1982) Purification of rat epididymal proteins ' $D$ ' and ' $E$ ', demonstration of shared immunological determinants, and identification of regional synthesis and secretion. Int. J. Androl. 5, 513-524.

Brooks, D.E. (1983) Effect of androgens on protein synthesis and secretion in various regions of the rat epididymis, as analysed by two-dimensional gel electrophoresis. Molec. cell. Endocr. 29, 255-270.

Brooks, D.E. \& Higgins, S.J. (1980) Characterization and androgen-dependence of proteins associated with luminal fluid and spermatozoa in the rat epididymis. J. Reprod. Fert. 59, 363-375.

Brooks, D.E., Hamilton, D.W. \& Mallek, A.H. (1974) Carnitine and glycerylphosphorylcholine in the reproductive tract of the male rat. J. Reprod. Fert. 36, $141-160$.
Brown, C.R., von Glos, K.I. \& Jones, R. (1983) Changes in plasma membrane glycoproteins of rat spermatozoa during maturation in the epididymis. J. Cell Biol. 96, 256-264.

Cameo, M.S. \& Blaquier, J.A. (1976) Androgen-controlled specific proteins in rat epididymis. J. Endocr. 69, 47-55.

Davis, B.J. (1964) Disc electrophoresis-II. Method and application to human serum proteins. Ann. N.Y. Acad Sci. 121, 404-427.

Dravlanu, E. \& Joshi, M.S. (1981) Sperm-coating antigens secreted by the epididymis and seminal vesicle of the rat. Biol. Reprod. 25, 649-658.

Faye, J.C., Duguet, L., Mazzuca, M. \& Bayard, F. (1980) Purification, radioimmunoassay, and immunohistochemical localization of a glycoprotein produced by the rat epididymis. Biol. Reprod. 23, 423-432.

Free, M.J. \& Jaffe, R.A. (1979) Collection of rete testis fluid from rats without previous efferent duct ligation. Biol. Reprod. 20, 269-278.

Garberi, J.C., Kohane, A.C., Cameo, M.S. \& Blaquier, J.A. (1979) Isolation and characterization of specific rat epididymal proteins. Molec. cell. Endocr. 13, 7382.

Hammerstedt, R.H., Hay, S.R. \& Amann, R.P. (1982) Modification of ram sperm membranes during epididymal transit. Biol. Reprod. 27, 745-754.

Hartree, E.F. (1972) Determination of protein: a modification of the Lowry method that gives a linear photometric response. Analyt. Biochem. 48, 422-427.

Hiipakka, R.A. \& Hammerstedt, R.H. (1978) Changes in 2-deoxyglucose transport during epididymal maturation of ram sperm. Biol. Reprod. 19, 1030-1035. 
Ivarie, R.D. \& Jones, P.P. (1979) A rapid sensitive assay for specific protein synthesis in cells and in cell-free translations: use of Staphylococcus aureus as an adsorbent for immune complexes. Analyt. Biochem. 97, 24-35.

Jones, R. \& Brown, C.R. (1982) Association of epididymal secretory proteins showing $\alpha$-lactalbumin-like activity with the plasma membrane of rat spermatozoa. Biochem. J. 206, 161-164.

Jones, R., Brown, C.R., von Glos, K.I. \& Parker, M.G. (1980) Hormonal regulation of protein synthesis in the rat epididymis. Characterization of androgendependent and testicular fluid-dependent proteins. Biochem. J. 188, 667-676.

Jones, R., Pholpramool, C., Setchell, B.P. \& Brown, C.R. (1981) Labelling of membrane glycoproteins on rat spermatozoa collected from different regions of the epididymis. Biochem. J. 200, 457-460.

Killian, G.J. \& Amann, R.P. (1973) Immunoelectrophoretic characterization of fluid and sperm entering and leaving the bovine epididymis. Biol. Reprod. 9, 489499.

Kohane, A.C., Garberi, J.C., Cameo, M.S. \& Blaquier, J.A. (1979) Quantitative determination of specific proteins in rat epididymis. J. Steroid Biochem. 11, $671-674$.

Kohane, A.C., González Echeverría, F.M.C., Piñeiro, L. \& Blaquier, J.A. (1980) Interaction of proteins of epididymal origin with spermatozoa. Biol. Reprod. 23, 737-742.

Laemmli, U.K. (1970) Cleavage of structural proteins during the assembly of the head of bacteriophage T4. Nature, Lond. 227, 680-685.

Laskey, R.A. (1980) The use of intensifying screens or organic scintillators for visualizing radioactive molecules resolved by gel electrophoresis. Meth. Enzymol. 65, 363-371.

Lea, O.A. \& French, F.S. (1981) Characterization of an acidic glycoprotein secreted by principal cells of the rat epididymis. Biochim. Biophys. Acta 668, 370-376.

Lea, O.A., Petrusz, P. \& French, F.S. (1978) Purification and localization of acidic epididymal glycoprotein (AEG): a sperm coating protein secreted by the rat epididymis. Int. J. Androl., Suppl. 2, 592-607.

Markwell, M.A.K. \& Fox, C.F. (1978) Surface-specific iodination of membrane proteins of viruses and eucaryotic cells using 1,3,4,6-tetrachloro-3 $\alpha, 6 \alpha$-diphenylglycoluril. Biochemistry, N.Y. 17, 4807-4817.

Moore, H.D.M. (1981) Glycoprotein secretions of the epididymis in the rabbit and hamster : localization on epididymal spermatozoa and the effect of specific antibodies on fertilization in vivo. J. exp. Zool. 215, 77-85.

Nicolson, G.L., Usui, N., Yanagimachi, R., Yanagimachi, H. \& Smith, J.R. (1977) Lectin-binding sites on the plasma membranes of rabbit spermatozoa. Changes in surface receptors during epididymal maturation and after ejaculation. J. Cell Biol. 74, 950962.

O'Farrell, P.H. (1975) High resolution two-dimensional electrophoresis of proteins. J. biol. Chem. 250, 40074021.

Olson, G.E. \& Danzo, B.J. (1981) Surface changes in rat spermatozoa during epididymal transit. Biol. Reprod. 24, 431-443.

Olson, G.E. \& Hamilton, D.W. (1978) Characterization of the surface glycoproteins of rat spermatozoa. Biol. Reprod. 19, 26-35.

Saling, P.M. (1982) Development of the ability to bind to zonae pellucidae during epididymal maturation: reversible immobilization of mouse spermatozoa by lanthanum. Biol. Reprod. 26, 429-436.

Voglmayr, J.K., Fairbanks, G., Jackowitz, M.A. \& Colella, J.R. (1980) Post-testicular developmental changes in the ram sperm cell surface and their relationship to luminal fluid proteins of the reproductive tract. Biol. Reprod. 22, 655-667.

Waites, G.M.H. (1977) Fluid secretion. In The Testis, Vol. 4, pp. 91-123. Eds A. D. Johnson \& W. R. Gomes. Academic Press, New York.

Wong, P.Y.D. \& Tsang, A.Y.F. (1982) Studies on the binding of a $32 \mathrm{~K}$ rat epididymal protein to rat epididymal spermatozoa. Biol. Reprod. 27, 12391246.

Wong, P.Y.D. \& Yeung, C.H. (1978) Absorptive and secretory functions of the perfused rat cauda epididymidis. J. Physiol., Lond. 275, 13-26.

Received 21 March 1983 